Concepts and Frameworks in English for Specific Purposes

\title{
Éditorial: Immanuel Kant and ESP’s New Frontier
}

\section{Anthony Saber}

\section{(2) OpenEdition}

\section{Journals}

Electronic version

URL: http://journals.openedition.org/asp/4823

DOI: 10.4000/asp.4823

ISSN: 2108-6354

Publisher

Groupe d'étude et de recherche en anglais de spécialité

\section{Printed version}

Date of publication: 9 March 2016

Number of pages: 1-6

ISSN: 1246-8185

\section{Electronic reference}

Anthony Saber, «Éditorial: Immanuel Kant and ESP's New Frontier », ASp [Online], 69 | 2016, Online since 15 March 2016, connection on 02 November 2020. URL : http://journals.openedition.org/asp/ 4823 ; DOI : https://doi.org/10.4000/asp.4823

This text was automatically generated on 2 November 2020.

Tous droits réservés 


\title{
Éditorial: Immanuel Kant and ESP's New Frontier
}

\author{
Anthony Saber
}

1 What can I know? What should I do? What may I hope? The famous fundamental questions of philosophy raised by Immanuel Kant's in The Critique of Pure Reason resonate with the issues that the editorial committee wished to tackle when preparing this special issue of ASP on "Concepts and Frameworks in ESP". With our readers' permission, we shall use those fundamental questions to explain our goals in this issue on the epistemology of ESP.

What can I know-in ESP? ESP is a science that studies words through words and, like many other human sciences, it depends on a certain number of crucial concepts to describe the phenomena that it investigates. ESP researchers routinely use such concepts as domain, genre, discourse community or specialized corpora, but one may wonder whether these categories stand on solid epistemological ground. In a previous issue of ASp, Margaret Rogers (2013: 6) described the notion of "domain" as "quite a slippery concept" that, in existing literature, may incorporate subject matter, social communities, cultural constructs, language and texts. Multiple definitions of discursive genres co-exist, both in the Francophone and in the Anglophone strands of discourse analysis: while Carolyn Miller (1984: 151-3) claims that

a rhetorically sound definition of genre must be centered not on the substance or the form of discourse but on the action it is used to accomplish [...], genre in this way becomes more than a formal entity; it becomes pragmatic, fully rhetorical, a point of connection between intention and effect, an aspect of social action[,]

3 John Swales (1990: 58) defines genres as "a class of communicative events, the members of which share some set of communicative purposes." Francophone researchers such as Jean-Michel Adam (1999: 93-94) posit that "discursive genres can be viewed as prototypical-stereotypical categories [...] that can be defined as trends or typicality gradients, by converging sets of regular traits rather than by very strict criteria", 1 while Catherine Kerbrat-Orecchioni and Véronique Traverso (2004: 41) distinguish genres used as common labels to designate texts such as a guidebook from genres categorized by deep text function ("thus, a guidebook can be viewed as a textual genre, 
but it should be in fact categorized as a juxtaposition of different discursive genres: descriptive, didactic, procedural, promotional..."). ${ }^{2}$ Although all these authors more or less share a teleological view of genres as texts that are purpose-oriented, it is clear from these examples that their respective epistemological stances vary considerably. And the fact that it would be perfectly legitimate to choose any of those conceptual frameworks to do ESP research leads to the rather disturbing conclusion that considerable epistemological variety may significantly affect the findings of ESP investigations on genres, thereby limiting prospects of cross-comparative analysis.

4 A more fundamental epistemological difficulty lies in the very concept of "specialization" in language. Michel Petit (2010: § 1) underlined the fact that "the main difficulty that arises when analyzing specialized discourse is [...] the sort of epistemological/methodological circularity that seems to support it [...]", as too little attention is devoted to reflecting on "what gives specialized discourse its specialized status, the latter often appearing as being taken for granted". ${ }^{3}$ When researchers in ESP assemble corpora in view of a given project, are they not driven, in the very process of choosing the texts they wish to include or exclude, by implicit assumptions about the "specialized" features that they wish to investigate? Should their results therefore be viewed as biased?

5 These doubts are compounded by the fact that, in the English language, the very name of "ESP" is endowed with a certain number of presuppositions that may be questioned -indeed, the phrase "for specific purposes" implies that "specialized" English is mainly delineated by language learners' needs, which ESP stakeholders in France (notably many members of GERAS, France's ESP flagship learned society) would not view as a totally appropriate definition. A significant proportion of researchers in "anglais de spécialite" (the phrase that is traditionally used in France for designating ESP) would probably be more inclined to adopt, instead of this purpose-driven definition of specialist English, a more essentialist definition, one in which specialized English is not a pedagogical construct, but first and foremost a "variety of English" 4 that can be observed in a given perimeter of society, delineated by professional or disciplinary boundaries. Michel Petit's (2010) theory of specialized domains exemplifies this type of conceptual framework. Petit posits that specialized domains are actual groupings of stakeholders that coalesce around three major "functions": an instructional function (fonction de formation), that helps outsiders become insiders through training and gatekeeping procedures; a regulatory function (fonction de régulation) that helps the community maintain a tight-knit structure and ensures that key rules are enforced; and an operational function (fonction d'exécution) which codifies a set of practices and skills needed to achieve the community's objectives (these skills may be of a disciplinary nature-i.e. flying an aircraft-or of a discursive nature-i.e. being able to efficiently communicate with air traffic control as per the rules of civil aviation phraseology).

6 Of note in any epistemological debate about ESP is the fact that, as highlighted by Laurence Anthony (2011), ESP's focus has significantly evolved over time, as a result of various epistemological choices. Anthony (2011:3) claims that "there have been several shifts towards and away from subject specificity": initial research efforts in the 1960s focused on "product-based approaches" that investigated the specific features of disciplinary language. A significant epistemological shift occurred when Hutchinson \& 
Waters (1987: 19) advocated adopting a wider view of "specialisms" and prioritizing language learning as the core subject of ESP:

[...] now there is a need for a wider view that focuses less on differences and more on what various specialisms have in common [...] what they have in common is that they are all primarily concerned with communication and learning. ESP should properly be seen not as any particular language product but as an approach to language teaching and learning which is directed by specific and apparent reasons for learning.

7 According to Anthony (2011: 4-5), a third major epistemological shift was observed at the end of the 1990s, as researchers capitalized on affordable and user-friendly concordancing tools to delve into disciplinary specialisms with a vengeance:

by the end of the 1990s there had been a shift back towards a 'narrow-angled' product-based approach focused on specialized varieties of English rather than the learning process itself. For example, in their seminal work Developments in English for Specific Purposes (1998), Dudley-Evans \& St. John explicitly mention the strong relationship between ESP and specific disciplines in their definition of ESP (1998: 4-5).

8 Those changes in focus and epistemological stance all seemed to be perfectly justified when they occurred, but may project an image of ESP as a discipline devoid of any clear focus of study. Physicists would all agree that, notwithstanding the various conceptual frameworks that they use to explain the phenomena that they observe, they share a common goal: understanding the universe. But if asked, "what is your main goal?" at an ESP conference, researchers in ESP-particularly in Francophone contexts-would probably respond in many different ways, given the highly fragmented nature of their discipline.

There is little doubt that more attention should be paid to obtaining more specific definitions of the concepts used in ESP research. Therefore, although on a much more modest scale than the famous German philosopher, we should follow Immanuel Kant down the path of radical doubt that led him to attempt and rebuild the very tenets of philosophy, by starting to establish ESP/ASP concepts on more solid theoretical ground.

One of the first issues that should be addressed is the nature of the communities where specialized varieties of English can be observed. Individuals that use a specialized variety of English do so because they somehow abide by a certain number of constraints that are shared by a circle of stakeholders-in other words, those individuals are affiliated with those circles, and this affiliation clearly shows through in the way they use the English language. As underlined by John Swales in the first article of this issue of ASp, an abundant list of labels have been used to designate these circles, notably Martin Nystrand's (1982) “discourse communities”, which John Swales (1991) later refined into "rhetorical discourse communities", i.e. groups that assemble to further common rhetorical goals, such as the dissemination of scientific research through scholarly publications. In an effort to reappraise the concept of discourse community (henceforth DC), Swales suggests that one should distinguish "local" DCs (for example, groups of people that work at a university department) from "focal" ones, which have a much broader geographical scope (the Southeast Michigan Birders, of which Swales is a distinguished member, belongs to the latter category). Local DCs may be residential, vocational or occupational, whereas focal DCs fall into two subcategories (recreational or professional). Hybrid forms of DCs may also exist-“folocal" 
communities, whose members have a double (and sometimes split) allegiance, as in the case of university scholars who, as both insiders at their own institution and members of transnational research associations, may simultaneously experience centrifugal and centripetal forces. Building on these novel definitions, Swales reconsiders the six criteria for identifying rhetorical DCs that he had originally described in Genre Analysis, and concludes that the concept of DC is not "a robust social construct" but is highly useful when addressing rhetorical configurations in discourse.

11 Specialized features of English are often construed as stemming from "professional" or "disciplinary" constraints. Professions and disciplines are concepts that merit close epistemological attention. This is an area where ESP is in great need of useful input from sociologists. Michel Dubois describes preconceptions and ill-grounded assumptions (e.g. the idea that disciplines could be envisaged as subdivisions of professions) in available sociological literature on these categories, and proposes criteria to differentiate them in the context of the sociology of science. While discipline appears to be the primary frame of reference when envisaging the cognitive processes and dominant cultural patterns that lead to the production of knowledge, professions (law or engineering for example) are applied in nature, in that they seek to use available knowledge to tackle human problems. Dubois offers illuminating insights on the differences between physicians and biologists: although researchers in ESP may grant both groups similar epistemological status as experts in a given domain, sociologists will acknowledge that both groups do share some key characteristics (specialist training, specialized knowledge and skills, normative subcultures and jurisdictional claims), but will also underline crucial differences-physicians develop a service relation to clients, whereas biologists' main focus is on scientific output.

12 In his contribution, Michel Van der Yeught offers a different perspective on the affiliation that links specialized stakeholders to a given domain, and takes issue with Michel Petit's view that specialized domains are actual "sectors of society". Drawing on conceptual frameworks proposed by Karl Popper and John Searle, Van der Yeught puts forward the concept of "specialised intentionality" as the driving principle in the emergence of specialized domains, which he defines as follows:

A specialised domain is therefore the autonomous linguistic and generally written expression of a complex intentional universe. It is made of focused and durable intentional states, their related intentional networks and background abilities that combine and interact to satisfy their beliefs and desires. To shorten the definition, I propose that specialised domains are sets of knowledge and practices which transcend their originators and are harnessed to the service of one particular purpose.

13 Key notions of Van der Yeught's novel epistemological system include specialized encyclopaedic competence and specialized implicature, which play a significant role in allowing access to the meaning of specialized utterances, thereby differentiating insiders from outsiders.

What can I know-in ESP? It is this editor's belief that the first three contributions to this issue of ASp provide some very useful answers. If we now move on to the second question raised by Immanuel Kant (what should I do?), we invite readers to review significant contributions by Christopher Gledhill and Natalie Kübler, David Banks, and Alex Boulton, which (respectively) cover three major conceptual frameworks often used to "do" ESP, i.e. to conduct actual empirical research on specialized phenomena in various corpora: linguistics-based approaches, diachronic ESP, and 
corpus-driven ESP research and learning. Each of these articles provides an extensive review of methods described by ESP practitioners in available literature, and offers insightful perspectives on current evolutions in ESP methodology.

Last but not least, Cédric Sarré and Shona Whyte offer highly valuable remarks on the emerging concept of "ESP didactics", which needs to be differentiated from "general" English language didactics. In their 1998 landmark book, Dudley-Evans and St John had identified "absolute" and "relative" characteristics of ESP viewed as an approach to English language teaching. Sarré and Whyte attempt to extend Dudley-Evans and St John's epistemological work by conducting an extensive review of key concepts in English didactics, which provides them with solid ground for identifying some distinctive features of ESP didactics, namely (1) a constant interaction between language and disciplinary knowledge, (2) goal-directedness, as ESP learning and teaching target highly specific skills that empower learners to perform "real-world" activities in the target language and (3) careful needs analysis.

Finally, the last question raised by Immanuel Kant is still pending: what may I hope? First, this journal hopes that by publishing, for the first time in ASp's history, an allEnglish issue, it may contribute to fruitful exchanges between "Anglophone ESP" and anglais de spécialité. Readers will note that I find it difficult to translate the latter term into English. As amply evidenced above, "French ESP" would not adequately describe the epistemological choices that are often observed in the French academic context. A tentative translation into English of anglais de spécialité could be "English in specialized domains" (ESD), but this is a provisional proposal that warrants further debates.

Secondly, this journal hopes that the reflections on "concepts and frameworks" offered in this issue will prompt further epistemological efforts by our colleagues. As exemplified in The Handbook of English of Specific Purposes edited by Brian Paltridge and Sue Starfield, a considerable body of knowledge has been amassed over the years by researchers in ESP on observable specialized features in the different "areas of ESP research" (Legal English, English for aviation, English for Academic Purposes, etc.). Yet, although questions about concepts and frameworks are implicitly raised in Part IV of the Handbook, entitled "Research Perspectives and Methodologies in ESP Rhetoric", which includes such chapters as "ESP and Intercultural Rhetoric" or "Ethnographic approaches in ESP research", what is actually discussed in those sections is the possible interdisciplinary nature of ESP, not its epistemological foundations. In this respect, it is not insignificant that, to the best of our knowledge, the Handbook's index does not include the word "epistemology" in its list of notions.

Epistemology is the next Frontier of ESP. Let us conquer it. Let us go there. Let us heed President John Fitzgerald Kennedy's call on September 12, 1962 at Rice University:

We set sail on this new sea because there is new knowledge to be gained [...]. We choose to go to the moon. We choose to go to the moon in this decade and do the other things, not because they are easy, but because they are hard, because that goal will serve to organize and measure the best of our energies and skills, because that challenge is one that we are willing to accept, one we are unwilling to postpone, and one which we intend to win. 


\section{BIBLIOGRAPHY}

ADAM, Jean-Michel. 1999. Linguistique textuelle. Des genres de discours aux textes. Paris: Nathan. ANTHONY, Laurence. 2011. "Products, processes and practitioners: A critical look at the importance of specificity in ESP”. Taiwan International ESP Journal 3/2, 1-18.

DUDLEY-EVANS Tony \& Maggie Jo ST JOHN. 1998. Developments in English for Specific Purposes: a multidisciplinary approach. Cambridge: Cambridge University Press.

HUTCHINSON Tom \& Alan WATERS. 1987. English for Specific Purposes: A learning-centred approach. Cambridge: Cambridge University Press.

KENNEDY, John Fitzgerald. 1962. "Moon Speech". Delivered at Rice University, Houston, Texas, on September 12. Retrieved from <http://er.jsc.nasa.gov/seh/ricetalk.htm> on 1 February 2016. KERBRAT-ORECCHIONI, Catherine \& Véronique TRAVERSO. 2004. “Types d'interactions et genres de l'oral". Langages 153, 41-51. <http://www.cairn.info/revue-langages-2004-1-page-41.htm>. MILLER, Carolyn. 1984, “Genre as social action.” Quarterly Journal of Speech 70, 151-167.

NYSTRAND, Martin. 1982. What Writers Know: The language, process, and structure of written discourse. New York: Academic Press.

PALTRIDGE, Brian \& Sue STARFIELD. 2013. The Handbook of English for Specific Purposes. Chichester: Wiley-Blackwell.

PETIT, Michel. “Le discours spécialisé et le spécialisé du discours : repères pour l'analyse du discours en anglais de spécialité." E-rea 8.1, Retrieved from <http://erea.revues.org/1400> on 1 February 2016.

RESCHE, Catherine. 2013. Economic Terms and Beyond: Capitalising on the Wealth of Notions. Bern: Peter Lang, Linguistic Insights 176.

ROGERS, Margaret. 2013. “What is a domain and is this a useful question?". ASp 64, 5-16.

SWALES, John M. 1990. Genre Analysis: English in academic and research settings. Cambridge: Cambridge University Press.

\section{NOTES}

1. "Les genres discursifs peuvent être considérés comme des «catégories prototypiquesstéréotypiques »[...] définissables par des tendances ou des gradients de typicalité, par des faisceaux de régularités et des dominantes plutôt que par des critères très stricts." (Our translation)

2. "Ainsi, on peut considérer un guide touristique comme un « genre » de texte, mais il relève en fait «de différents 'genres' » de discours : descriptif, didactique, procédural, promotionnel..." (Our translation)

3. "La principale difficulté que nous paraît soulever l'analyse du discours spécialisé [...] [est] la sorte de circularité épistémologico-méthodologique qui paraît la sous-tendre. Il nous semble en effet que l'analyse du discours, telle qu'elle est diversement mise en œuvre en matière de discours spécialisé, s'attache plus volontiers à la mise en lumière de certaines caractéristiques des discours dont elle traite qu'à la réflexion sur ce qui fonde leur statut même de discours 
spécialisé, ce statut paraissant le plus souvent être simplement tenu pour acquis a priori." (Our translation)

4. Catherine Resche (2013) uses this term to describe English for economics. Anthony (2011: 4) also used it to describe specialized discourse.

\section{AUTHOR}

\section{ANTHONY SABER}

Editor in chief. anthony.saber@ens-cachan.fr 